\section{Hvordan avdekke depresjon hos ungdom}

Tre enkle spørsmål stilt av fastlegen kan avdekke depresjon hos unge.

Depresjon hos ungdom er et relativt vanlig og alvorlig problem. Fastlegen er gjerne den som først kommer i kontakt med slike pasienter og har derfor muligheten til å stille diagnose tidlig. Det finnes likevel få enkle, validerte verktøy for å screene for depresjon. I en norsk studie har man undersøkt om man kan oppdage depresjoner ved å stille tre enkle spørsmål (1).

Studien omfattet nesten 300 pasienter i alderen 14-16 som først ble stilt tre enkle spørsmål: Har du i løpet av den siste måneden vært plaget med å føle deg nedfor, deprimert eller uten håp? Har du i løpet av den siste måneden ofte vært plaget med lite interesse eller glede ved å gjøre ting? Er dette noe du vil søke hjelp for? Et strukturert diagnostikkintervju (Composite International Diagnostic Interview, CIDI) ble brukt som gullstandard. De tre spørsmålene viste seg å ha en positiv prediktiv verdi på $31 \%$ og en negativ prediktiv verdi på $97 \%$.

- Denne studien viser at svarene på tre nøkkelspørsmål, to om kjernesymptomer og et om hjelpebehov, stilt av fastleger til ungdom som oppsøker sin fastlege for ulike helseplager, kan gi pålitelige holdepunkter for om det foreligger depressive symptomer, sier Marit Hafting, overlege ved Barne- og ungdomspsykiatrisk poliklinikk på Voss.

- Utfordringen i praksis blir å få fastleger til å huske på problemstillingen når de har ungdommer som pasienter. Fastleger må ta seg tid til undersøke hvordan pasienten har det. Med utgangspunkt i svarene på nøkkelspørsmålene må ungdommene følges opp videre der det er mistanke om depresjon, sier Hafting.

\section{Kaveh Rashid}

Tidsskriftet

\section{Litteratur}

1. Haugen W, Haavet OR, Sirpal MK et al. Identifying depression among adolescents using three key questions: a validation study in primary care. $\mathrm{Br}$ J Gen Pract 2016; 66: e65-70.

\title{
Rotavirusvaksiner virker
}

\author{
Vaksiner mot rotavirus i lavinntektsland gir færre sykehusinnleggelser \\ av barn under fem år og lavere dødelighet hos spedbarn.
}

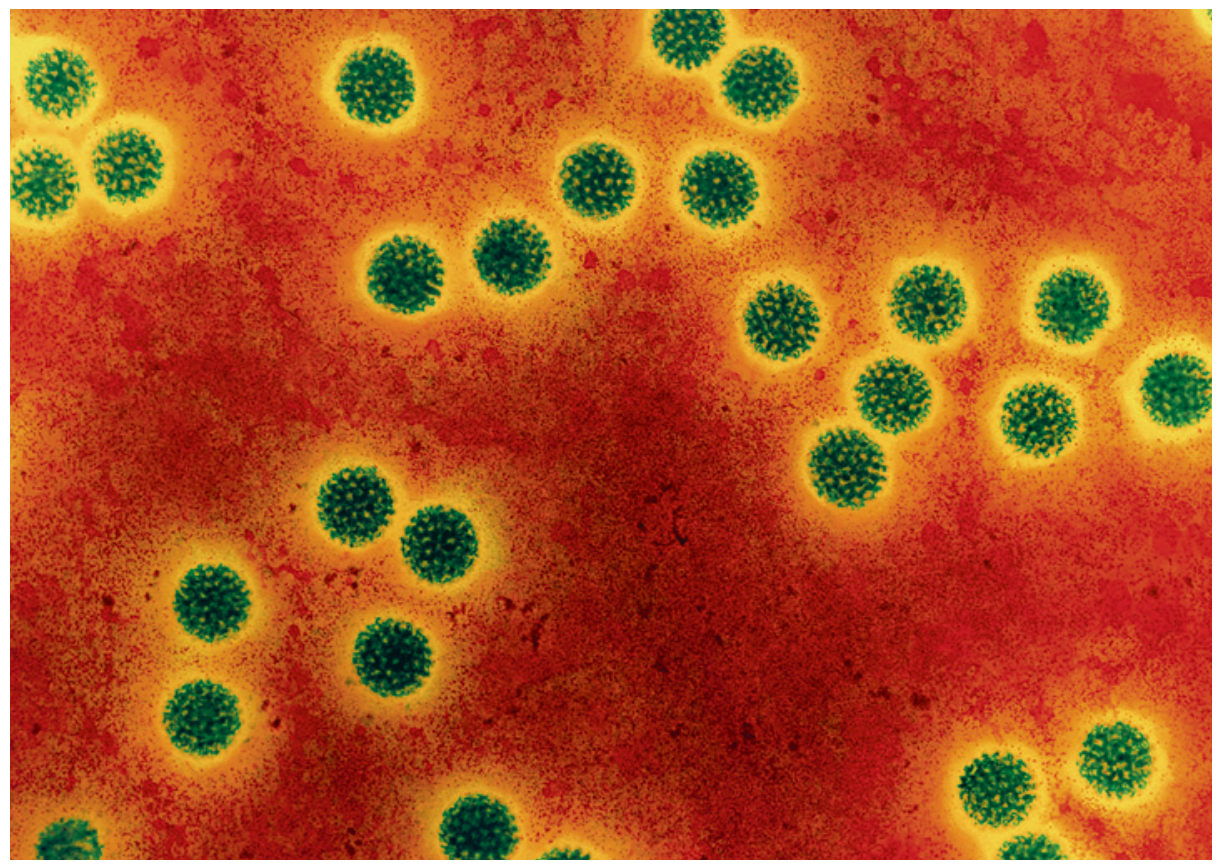

Farget elektronisk mikrofotografi (Coloured transmission electron micrograph, TEM) av rotavirus. Viruset har fått navnet på grunn av sitt hjullignende utseende. Foto: Science Photo Library

I 2006 kom det to ny rotavirusvaksiner på markedet - en monovalent og en pentavalent. Begge vaksinene har vist seg å være effektive for å forebygge gastroenteritt hos barn i høyinntektsland. Om effekten er like god i lavinntektsland, har vært uklart (1).

Den monovalente vaksinen ble innført i Botswana i desember 2012. Gjennom studier basert på fire sykehusregistre ble antall sykehusinnleggelser og dødsfall som følge av gastroenteritt hos barn, sammenlignet før og etter innføring av vaksinen (2). I perioden 2009-12 førte gastroenteritt hvert år til 1212 sykehusinnleggelser av barn under fem år og 77 dødsfall hos barn under to år. I perioden etter innføring av vaksinen var tallene henholdsvis 937 og 60 årlig. Nedgangen var statistisk signifikant for innleggelser, men ikke for dødsfall, bortsett fra ved analyse av dødsfall hos barn under ett år.

Mexico innførte den pentavalente vaksinen i 2007, men byttet til den monovalente vaksinen i 2011. Forskere har sett på hospitalisering og død for perioden 2003-14 (3). I årene etter vaksinering var det en reduksjon på $47 \%$ i diarérelaterte sykehusinnleggelser blant barn under fem år og $53 \%$ i diarérelaterte dødsfall sammenlignet med perioden før vaksinering (3).

Tilsvarende studier med lignende resul- tater fra bl.a. Sør-Afrika, Ghana, Rwanda, Togo, Zambia, Armenia, Moldova, Israel, Bolivia, Guatemala og Nicaragua ble publisert i samme nummer av det samme tidsskriftet. I en ledsagende lederartikkel påpekes det at studiene viste en tidsmessig sammenheng med innføring av vaksinen, at nedgangen var størst i rotavirussesongene, og at størst effekt ble sett hos spedbarn (1). Noen, men ikke alle studiene, viste flokkimmunitet. Per september 2015 hadde 36 lavinntektsland tatt inn rotavirusvaksine i sine nasjonale vaksinasjonsprogrammer.

\section{Kristoffer Brodwall}

kristoffer.brodwall@gmail.com

Institutt for global helse og samfunnsmedisin Universitetet i Bergen

\section{Litteratur}

1. Parashar UD, Johnson $H$, Steele AD et al. Health impact of rotavirus vaccination in developing countries: progress and way forward. Clin Infect Dis 2016; 62 (suppl 2): S91-5.

2. Enane LA, Gastañaduy PA, Goldfarb DM et al. Impact of rotavirus vaccination on hospitalizations and deaths from childhood gastroenteritis in Botswana. Clin Infect Dis 2016; 62 (suppl 2): S168-74.

3. Sánchez-Uribe E, Esparza-Aguilar M, Parashar UD et al. Sustained reduction of childhood diarrhearelated mortality and hospitalizations in Mexico after rotavirus vaccine universalization. Clin Infect Dis 2016; 62 (suppl 2): S133-9. 